\title{
Phytolith analysis in Quaternary fluvial deposits (El Palmar Formation-Late Pleistocene) of the Uruguay River valley, Entre Ríos province, Argentina
}

\author{
Noelia I. Patterer ${ }^{\mathrm{a}, \mathrm{b}, *}$, Daniela M. Kröhling ${ }^{\mathrm{c}}$, Alejandro F. Zucol ${ }^{\mathrm{a}, \mathrm{b}}$ \\ ${ }^{a}$ Laboratorio de Paleobotánica, Centro de Investigación Científica y de Transferencia Tecnológica a la Producción, CICYTTP(CONICET-PROV. E.R.-UADER), España 149, \\ Diamante, E3105BWA, Entre Ríos, Argentina \\ ${ }^{\mathrm{b}}$ Facultad de Ciencia y Tecnología-UADER, Ruta 11, $10.5 \mathrm{~km}$ Oro Verde, E3100, Paraná, Entre Ríos, Argentina \\ ${ }^{\mathrm{c}}$ CONICET and Universidad Nacional del Litoral, Facultad de Ingeniería y Ciencias Hídricas, CC 217, 3000, Santa Fe, Argentina
}

A R T I C L E I N F O

\section{Keywords:}

Phytoliths

Late Pleistocene

El Palmar Formation

Uruguay River valley

Argentina

\begin{abstract}
A B S T R A C T
The phytolith assemblages of the El Palmar Formation (Late Pleistocene) are presented together with general stratigraphic and sedimentological data. The El Palmar Formation represents a channel system of the Uruguay river (South America) with longitudinal sandy gravel and gravelly sand bedforms, and associated floodplain deposits. The phytolith content of the unit was analyzed along the profiles on the right bank of the river in the middle reach (eastern Entre Ríos province, Argentina). Four outcropping profiles of the El Palmar Fm. were selected for detailed analyses: Santa Ana (Federación department), La Chola quarry, El Palmar National Park and Nueva Escocia (Colón department) localities. The herbaceous palaeoflora of the El Palmar Fm. is represented by mixed environments, such as meso-megathermic grassland with the presence of palm trees in a savanna ecosystem and micro-environments with aquatic plants and bamboo grasses that characterized a stratified forest in humid environments with high water availability. The reconstructed vegetation pattern is composed of a stratified gallery forest changing to temperate savanna, extended along the upper basin of the Uruguay river and occupying the river valley in the middle reach of the basin. The data contribute to the palaeobiodiversity knowledge of Quaternary fluvial sedimentary units of South America. In addition, the results give a better understanding of the evolutionary history of some vegetal communities, and especially the present palm trees of the El Palmar National Park reserve, as part of a relict flora that has inhabited the area since, at least, the Upper Pleistocene. The geological and micro-paleobotanical records of the El Palmar Fm. lead to the inference of general warm and humid conditions during most of the deposition of the formation, probably covering part of the last major interglacial period before the present (MIS 5).
\end{abstract}

\section{Introduction}

The Uruguay river drains an area of $365,000 \mathrm{~km}^{2}$ and connects the humid tropical region in southern Brazil with the humid temperate Pampean region in Argentina and Uruguay, being one of the largest fluvial systems in South America (Iriondo and Kröhling, 2008). Its upper basin has developed in a landscape represented by Late Cretaceous-Cenozoic planation surfaces that formed on the Paraná Basaltic Plateau (Kröhling et al., 2014). The middle and lower Uruguay river basins are characterized by Quaternary sedimentary units, representing different environmental conditions. Among them, the El Palmar Formation is the main geological unit deposited by the Uruguay river in the middle basin (in eastern Entre Ríos province, Argentina, and northwestern Uruguay) during the Upper Pleistocene (Iriondo and Kröhling, 2008). It composes the upper fluvial terrace of the Uruguay river,
4-20 km wide on both recent river margins, generated by a gravellysandy river. The main lithological features of the El Palmar Fm. are sandy strata with interbedded gravels, red to yellowish brown in colour, with typical thicknesses of 10-15 m. The sources of the materials are Mesozoic rocks of the upper Uruguay basin, mainly composed of sandstones and basalts (in southwestern Brazil and northeastern Argentina; Iriondo and Kröhling, 2008). El Palmar Fm. is correlated with the Salto Fm., defined in Uruguay by Bossi (1969), and considered as a member of the Salto depositional sequence by Veroslavsky and Ubilla (2007), represented by bedload deposits in low sinuosity and highly mobile, broad, shallow channels (Ubilla and Martínez, 2016).

Absolute datings (thermoluminescense) of the upper section of the El Palmar Fm. gave ages between ca. 80 and 88 ka. BP (Iriondo and Kröhling, 2008), that would represent the warm substage MIS 5a -marine isotope stage (MIS)- Kröhling (2009). Recently, an OSL

\footnotetext{
* Corresponding author. postal address: CICYTTP-CONICET, España 149, Diamante, E3105BWA, Entre Ríos, Argentina.

E-mail addresses: noeliapatterer@gmail.com (N.I. Patterer), dkrohling@santafe-conicet.gov.ar (D.M. Kröhling), cidzucol@gmail.com (A.F. Zucol).
} 
(optical stimulated luminescence) dating of sediments from the upper section taken in the type area (El Palmar National Park) yielded an age of 184,491 \pm 13,946 years BP (Lab Code L0090, Laboratório de Espectrometria Gama e Luminescência, USP, Brazil). This result would extend the age of the El Palmar Fm. to the penultimate interglacial, MIS 7-Middle Pleistocene- (Ramos et al., 2017a).

Phytolith analysis is a valuable tool in the palaeoenvironmental reconstruction of sedimentary sequences, regional hydrosedimentological dynamics and geological fluvial units (Patterer, 2012; Calegari et al., 2017). Palaeobotanical research in Argentina has shown important growth in the last 10 years, mainly related to fossil wood and phytoliths in Quaternary sedimentary units (Zucol et al., 2005; Brea et al., 2010; Brea and Zucol, 2011; Patterer and Brea, 2011; Patterer, 2012, Patterer et al., 2014; Ramos et al., 2012, 2017a,b). Zucol et al. (2005) described the first phytolith assemblages in a sedimentary profile of the type area of the El Palmar Fm., and Ramos (2015) complemented the knowledge of its palaeoflora with a study of petrified wood remains from this area. In general, the El Palmar Fm. outcrops at the present topographic surface of the upper fluvial terrace in this area, and Butia yatay (Mart.) Becc. populations grow in the present soil developed on the El Palmar Fm. in El Palmar National Park (31 ${ }^{\circ} 55^{\prime}$ S; $58^{\circ}$ $\left.16^{\prime} \mathrm{W}, 8500 \mathrm{ha}\right)$. This species is an endemic of the temperate-humid savannas of southern South America. This area belongs to the Espinal eco-region, with typical grassland and gallery forest species (Dinerstein et al., 1995). The evolution of the Quaternary vegetation and its paleoenvironmental interpretation of the Uruguay river basin are still only poorly documented from the herbaceous vegetation records. Main contributions are from the palaeoxylological works of Lutz (1979, 1980, 1984, 1986); Brea (1998, 1999); Brea et al. (2010) and Ramos et al. (2012, 2017a,b). The first mammal fossil record of the El Palmar Fm. is the Stegomastodon platensis Ameghino (Tonni, 1987), a vertebrate fossil from the Lujanian SALMA (South American Land Mammal Age; Late Pleistocene-Early Holocene). The fossil record was incremented by the identification of eight new taxa (Ferrero et al., 2007): Megatherium americanum (Megatheriidae: Megatheriinae), Mylodon darwini (Mylodontidae: Mylodontinae), Macrauchenia patachonica (Litopterna: Macraucheniidae), Toxodon cf. platensis (Notoungulata; Toxodontidae), Tapirus cf. terrestris (Perissodactyla: Tapiridae), Equus (Amerhippus) $c f$. neogeus (Perissodactyla: Equidae), Morenelaphus $c f$. lujanensis, Antifer $s p$. (Artiodactyla: Cervidae) and Stegomastodon platensis (Proboscidea: Gomphotheriidae); the fossil assemblage postulates a Lujanian age. Brandoni et al. (2010) described also a Mylodon darwini.

In this contribution, we delve into the knowledge of the evolutionary history of the herbaceous communities by means of the phytolith content of the outcropping El Palmar Fm. and complemented with general stratigraphic and sedimentological data that contribute to palaeoenvironmental reconstructions of the Upper Pleistocene in northeastern Argentina and western Uruguay.

\section{Study area and geological setting}

The study area comprises the type area of the El Palmar Fm. (Fig. 1), between Concordia (Entre Ríos province, Argentina) and El Palmar National Park (Colón department, Entre Ríos province). The unit crops out at the upper fluvial terrace surface; vertical profiles are mainly located in quarries along the terrace. The unit covers Cretaceous rocks unconformably; locally a Late Holocene aeolian sandy unit lies on top of the El Palmar Fm.

The channel deposits of the El Palmar Fm. are represented by channel lag gravels, longitudinal gravel bars and low-angle crossbedded sand bars. Laminated fine sands to clayey silts represent abandoned channel infillings and overbank deposits. The outcrops show a fining-upward trend, in general composed of very poorly sorted quartz sands organized in tabular to lenticular strata, yellow/yellowish brown to red in colour, massive or with trough-cross stratification. It contains lenticular strata, mainly composed of fine to medium and well- rounded siliceous pebbles and medium to coarse well-rounded gravels in a sandy/clayey matrix, with planar bedding, that indicates high fluvial transport energy and high-river discharges. The facies association and the architecture represent a bedload (braided) river. The El Palmar Fm. was cemented differentially by silica and iron oxides. The relict terraces dominated the landscape in some sectors, because of the epigenetic processes affected the upper part of the El Palmar Fm. locally, generating highly silicified sandy bodies.

The study area currently experiences a subtropical humid climate with mean annual temperature and precipitation of $18.6{ }^{\circ} \mathrm{C}$ and $1300 \mathrm{~mm}$, respectively.

\section{Materials and methods}

The phytolith content was analyzed in four outcropping profiles of the El Palmar Fm.: Santa Ana profile (Santa Ana site, Federación department); José Etchepare profile (La Chola quarry, Colón department); Los Loros profile (El Palmar National Park, Colón department) and Nueva Escocia profile (Nueva Escocia site, Colón department) (Fig. 1). Fieldworks comprised the description of sediments and beds, their lithologic attributes, sedimentary structures, strata geometries, and sampling. Lithofacies (Table 1) were defined and coded according to Miall (1996, 1997).

The sediment sampling for phytolith analysis, was carried out by mainly taking account of the grain-size variations along the selected sedimentary profiles. In particular, samples were taken vertically every $10 \mathrm{~cm}$ where the fine sediment predominated (e.g. clays and fine sands), whereas in the coarse sediments (e.g. pebbly to gravelly sands) only one or two representative samples were collected.

The method of Zucol et al. (2010) was applied for phytolith extraction and adapted for samples of fluvial origin (Patterer, 2012; Patterer et al., 2016). The initial weight of the sediment was $1500 \mathrm{~g}$, with the collection of material of diameters less than $250 \mu \mathrm{m}$. Different chemical agents were used to remove soluble salts, organic matter and carbonates. Particle size fractions were obtained through sieving (coarse fraction) and sedimentation (fine fractions), obtaining four fractions: fine $(<7.8 \mu \mathrm{m})$, medium $(7.8-53 \mu \mathrm{m}$ and $53-250 \mu \mathrm{m})$, and coarse $(>250 \mu \mathrm{m})$. Densimetric separation of the medium grain-size fractions was made in a sodium polytungstate solution with a density of $2.3 \mathrm{~g} / \mathrm{cm}^{3}$. Phytoliths were mounted on microscope slides in both liquid (oil immersion) and solid (Canada balsam) media. Between 300 and 400 phytoliths per sample were counted using an optical microscope Nikon Eclipse E200. Phytolith morphotypes (Table 2) were determined and classified according to the regulations and descriptors proposed by ICPN 2.0 (Neumann et al., 2019), and the acronyms suggested by Patterer et al. (2011). The Palm tree Index (Pt) was applied. Patterer et al. (2019) defined this phytolith index (Pt) as the ratio of the spheroid echinate phytolith morphotypes in relation to the sum of the grass phytoliths (Poaceae diagnostic short cells).

\section{Results}

\subsection{Sedimentological and phytolith descriptions}

Santa Ana Profile ( $30^{\circ} 54^{\prime} 50.6$ "S; 57 $\left.{ }^{\circ} 55^{\prime} 46.5^{\prime \prime} \mathrm{W}\right)$. The El Palmar Fm. outcrop is $4.00 \mathrm{~m}$ thick along a trench (Fig. $2 \mathrm{~A}$ ). The lower section of the profile ( $1.05 \mathrm{~m}$ thick) is formed by a medium sandy bed (very poorly sorted sand, from very fine to very coarse quartz sand, red in colour; Sm facies), covered by a thick lenticular bed composed of massive grey clays with evidence of gleying (Fsm facies) (Fig. 3). The middle section of the profile ( $1.30 \mathrm{~m}$ thick) represents an active channel (Fig. 3 A): a very thick bed composed of very poorly sorted quartz sands, massive (Sm facies) to medium/thick strata, dominantly formed by matrix-supported graded gravels to gravelly sands (Gmg facies) and fining upward to a thin bed formed by massive silty clays (Fsm/Fm facies). The materials are red to yellowish red in colour (iron-oxide 


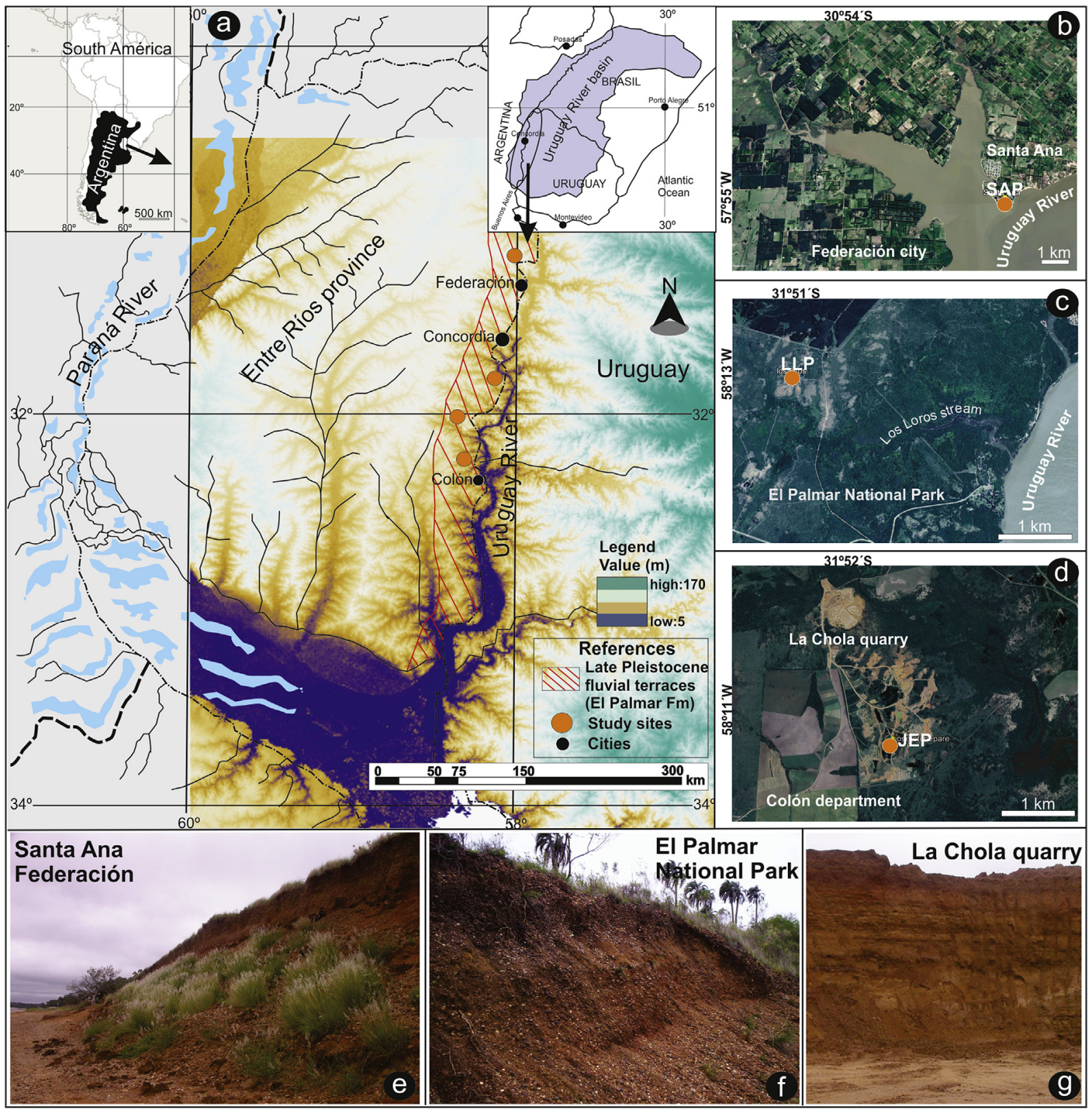

Fig. 1. Location map showing the El Palmar Formation distribution and fossiliferous localities. a. DEM of the eastern margin of Entre Ríos province. b. Santa Ana locality in Federación City (SAP: Santa Ana profile). c. Los Loros site in El Palmar National Park locality (LLP: Los Loros profile). d. La Chola quarry site (JEP: José Etchepare profile). e and f. Outcrops of the El Palmar Formation. g. The El Palmar Formation in a quarry.

Table 1

Main lithofacies based on Miall $(1977,1996)$ identified from the profiles studied of the El Palmar Formation in this study.

\begin{tabular}{|c|c|c|}
\hline Facies & Description & Interpretation \\
\hline $\mathrm{Gm}$ & Sandy matrix-supported pebbles and/or cobbles, massive or with horizontal bedding & Longitudinal bars. Lag deposits \\
\hline Gmg & $\begin{array}{l}\text { Sandy matrix-supported graded gravels. } \\
\text { Gravelly sands, massive or with normal grading }\end{array}$ & Gravelly and sandy bedforms \\
\hline Gh & $\begin{array}{l}\text { Horizontally stratified sandy matrix-supported gravels. Clast-supported pebbles and cobbles, with } \\
\text { horizontal bedding }\end{array}$ & Lag at the base of a channel deposit. Longitudinal bedforms \\
\hline Gp & Matrix supported pebbles and cobbles, with planar cross-stratification & Linguoid bars. Transverse bedforms \\
\hline St & Fine to very coarse sands with trough cross-stratification & Dunes (lower flow regime) \\
\hline $\mathrm{Sm}$ & Fine to very coarse sands, massive & Shallow flow deposits \\
\hline Sp & Fine to very coarse sands, with planar cross-stratification & $\begin{array}{l}\text { Linguoid and transverse bars, sand waves (lower flow } \\
\text { regime) }\end{array}$ \\
\hline Sh & Fine to very coarse sands, with horizontal stratification/lamination & Planar bed flow (lower and upper regime) deposits \\
\hline $\mathrm{Fl}$ & Fine sand, silt or mud, with fine lamination & Overbank and abandoned channel deposits \\
\hline $\mathrm{Fm} / \mathrm{Fsm}$ & Silt, clay or mud, massive, with desiccation cracks & Overbank and abandoned channel deposits \\
\hline
\end{tabular}


Table 2

Morphological classification of phytoliths: Major groups ${ }^{\mathrm{a}}$ (Neumann et al., 2019); Acronyms ${ }^{\mathrm{b}}$ (Patterer et al., 2011) and their graphical references.

\begin{tabular}{|c|c|c|c|}
\hline Major groups $^{\mathrm{a}}$ & Principal botany affinity & Acronym $^{\mathrm{b}}$ & Figures \\
\hline \multicolumn{4}{|c|}{ Non diagnostic grass phytoliths } \\
\hline \multirow[t]{5}{*}{ Bulliform flabellate } & Poaceae & Fl03 & Fig. 5 A: a, b \\
\hline & & Fl04 & Fig. 5 A: c, d and j \\
\hline & & Fl05 & Fig. 5 A: g, h e i \\
\hline & & Fl08 & Fig. 5 A: e and k \\
\hline & & Fl07 & Fig. 5 A: $\mathrm{f}$ and 1 \\
\hline \multirow[t]{3}{*}{ Elongate } & & Mp08 & Fig. 5 B: $a$ and $b$ \\
\hline & & Mp09 & Fig. 5 B: c, d, e and f \\
\hline & & Mp01 & Fig. 5 B: $g$ \\
\hline \multirow[t]{4}{*}{ Acute bulbosus } & & Ac01 & Fig. 5 C: $\mathrm{a}$ and $\mathrm{b}$ \\
\hline & & $\mathrm{Ac0} 2$ & Fig. 5 C: c \\
\hline & & Ac06 & Fig. 5 C: $\mathrm{d}$ and $\mathrm{e}$ \\
\hline & & Ac04 & Fig. 5 C: $\mathrm{f}$ \\
\hline \multirow[t]{5}{*}{ Blocky } & & $\mathrm{Sx} 02$ & $\begin{array}{l}\text { Fig. } 5 \text { D: } a, b, f, d \\
\text { and } g\end{array}$ \\
\hline & & Sx01 & Fig. 5 D: c \\
\hline & & $\mathrm{Sx} 03$ & Fig. 5 D: h \\
\hline & & Mx03 & Fig. 5 D: e and j \\
\hline & & Mx02 & Fig. 5 D: i, $\mathrm{k}$ and $\mathrm{l}$ \\
\hline \multicolumn{4}{|c|}{ Grass silica short-cell phytoliths (GSSCP) } \\
\hline \multirow[t]{4}{*}{ Bilobate } & Panicoideae & $\mathrm{Ha01}$ & Fig. 6 B: $a$ and $b$ \\
\hline & & $\mathrm{Ha} 08$ & Fig. 6 B: $\mathrm{c}$ and d \\
\hline & & Ha10 & Fig. 6 B: e and f \\
\hline & & $\mathrm{Ha03}$ & Fig. 6 B: $g$ \\
\hline \multirow[t]{3}{*}{ Rondel } & Danthonioideae & Ct01 & Fig. 6 C: a \\
\hline & & Ct03 & Fig. 6 C: b, c and d \\
\hline & & Ct07 & Fig. 6 C: e \\
\hline \multirow[t]{2}{*}{ Saddles } & Chloridoideae & Sm01 & Fig. 6 D: a, b and c \\
\hline & & $\mathrm{Sm} 03$ & Fig. 6 D: d \\
\hline \multirow[t]{2}{*}{ Trapezoid } & Pooideae & Oc01 & Fig. 6 D: $a$ and b \\
\hline & & Oc02 & Fig. 6 D: c \\
\hline \multicolumn{4}{|l|}{ Non grass phytoliths } \\
\hline Spheroid echinate & Palms & Gl04 & Fig. 6 A: a, b c and d \\
\hline Speheroid psilate & Woody Dicots & Mg01 & Fig. 6 A: $\mathrm{e}$ \\
\hline Spheroid ornate & & Gl05 & Fig. $6 \mathrm{~A}: \mathrm{f}$ and $\mathrm{g}$ \\
\hline \multirow[t]{2}{*}{ Laminate elongates } & Podostemaceae & Ln02 & Fig. 5 E: $\mathrm{a}$ and $\mathrm{b}$ \\
\hline & & Ln03 & Fig. 5 E: c \\
\hline \multirow[t]{3}{*}{ Tracheids } & Dicots & Du01 & Fig. 6 F: $a$ and $b$ \\
\hline & & Du02 & Fig. 6 F: $\mathrm{c}$ and d \\
\hline & & Du04 & Fig. 6 F: e \\
\hline
\end{tabular}

cements). The upper section of the profile $(1.40 \mathrm{~m})$ is formed by strata of massive to crudely stratified matrix-supported sandy gravels (Gm and Gh facies) and gravelly sands (Gmg facies) in an imbricated and a fining upward pattern, crowned by a lag gravelly deposit (Gh facies), 0.50-0.80 m thick (Fig. 3). Well-rounded and disc-shaped clasts of the gravelly beds are mainly siliceous, with subordinated basaltic petrologies (Fig. 3 B). The upper part of the profile was affected by pedogenesis.The interpretation of the association of the sedimentary facies of this outcrop indicates a major fluvial channel with longitudinal sandy gravel and gravelly sand bedforms.

The phytolith presence was recorded in the first $2.00 \mathrm{~m}$ of the profile. Non-diagnostic grass phytoliths, such as bulliform flabellate (Fig. $5 \mathrm{~A}$ ) and elongate elements (Fig. 5 B), acute bulbosus (Fig. 5 C), and blocky morphotypes (Fig. $5 \mathrm{D}$ ), predominated in the first $0.80 \mathrm{~m}$ of the profile (lag gravelly deposit). A significant percentage of palm spheroid and spheroid psilate/ornate of herbaceous/woody-dicot phytoliths (Fig. 6 A) was observed. Diagnostic grass phytoliths appeared frequently and some morphotypes stood out, especially the bilobates (Fig. 6 B; convex lobes, short shank and long shank; concave lobes, very short shank); rondel types (Fig. 6 C) and saddles (Fig. 6 D), together with scarce oblong and crenate morphotypes (Fig. 6 E).

In the remaining $1.20 \mathrm{~m}$, larger and non-diagnostic phytoliths (elongate, bulliform flabellate, acute bulbosus, blocky) dominated the assemblage, accompanied by a large percentage of undifferentiated phytoliths (possibly worn out morphotypes). The lower and middle section of the profile did not present any phytolith remains.
The Pt index in the samples of the upper section showed medium values (20\%) and the plant communities presented a physiognomy of shrubbery with isolated tall palms. In the samples of the lower section, spheroid echinate morphotypes are not observed, so therefore the $\mathrm{Pt}$ index was not applied (Fig. 7).

Nueva Escocia profile ( $31^{\circ} 38^{\prime} 3.7^{\prime \prime}$ S, $\left.58^{\circ} 00^{\prime} 48.5^{\prime \prime} \mathrm{W}\right)$. The El Palmar Fm. outcrops along a $3.45 \mathrm{~m}$ thick excavated profile, represented by interbedded gravelly, sandy and clayey medium strata, reddish yellow in general colour, composing fining-upward sequences (Fig. 2 B). The lower sequence ( $1.58 \mathrm{~m}$ thick) begins with medium lenticular beds formed by matrix-supported (poorly sorted quartz sand) well-rounded and disc-shaped pebbles and cobbles (mainly chalcedony and quartz), massive to flat bedding ( $\mathrm{Gm}$ facies); intercalated with medium beds of poorly sorted quartz sands (Fig. $3 \mathrm{C}$ ) massive to horizontally stratified (Sh facies). A thick gravelly bed coarsening upwards, matrix supported (poorly sorted quartz), with planar cross-stratification (Gp facies), is lying on the medium gravelly bed and it is covered by a medium bed formed by massive sands containing fine intercalated clayey lens (Sm facies). It is capped by a medium bed of massive greyish brown clays (Fm facies). The following sequence $(1.60 \mathrm{~m}$ thick) is formed by fine beds of poorly sorted quartz sands, yellowish orange in colour, with fine lenses of intercalated clay ( $\mathrm{Sm}$ facies), a medium bed of sandy-supported cobbles ( $\mathrm{Gm}$ facies), and a medium bed of massive greyish brown clays (Fm facies), interpreted as the infill of an abandoned channel. A set of medium beds formed by iron-oxide cemented sands, reddish yellow in colour, massive, or with planar cross-bedding ( $\mathrm{Sm}$ and $\mathrm{Sp}$ facies), begins the last sequence of the profile. It is capped by a clast-supported thin bed formed of poorly sorted cobbles with highly siliceous and iron-oxide cement (Gcm facies), with an overlying thin bed of massive clays (Fm facies). The upper section of the profile is composed of a thin bed of cemented sand (sandstone), with a crossbedded trough (St facies), reddish yellow in colour, covered by a gravelly lag (Gh facies; $0.20-0.30 \mathrm{~m}$ thick).

The association of the sedimentary facies of this profile represents a major fluvial channel with longitudinal sandy gravel bedforms. Regarding the analysis of siliceous micro remains, this profile did not show any phytoliths, mainly due to the epigenetic processes that occurred in these deposits.

Los Loros profile $\left(31^{\circ} 51^{\prime} 24.3^{\prime \prime} \mathrm{S}, 58^{\circ} 14^{\prime} 0.27^{\prime \prime} \mathrm{W}\right)$. This coarseningupward profile ( $3.80 \mathrm{~m}$ thick, Fig. $2 \mathrm{C}$ ) begins with a thick bed of very poorly sorted quartz sands, red in colour (Fig. $3 \mathrm{C}$ ) massive (Sm facies) to planar horizontally stratified (Sh facies). It is overlaid by a thin to medium bed composed of a reddish brown horizontally laminated loam (Fl facies). Thin gravelly strata, reddish brown to yellowish brown in colour, define the rest of the profile ( $3 \mathrm{~m}$ thick), individually formed by sandy loam matrix-supported cobbles (well-rounded to subrounded, blade to disc-shaped clasts, weakly imbricated and mainly formed by basalt and quartz; Gm facies), with cement of iron oxides. The proportion of the sandy matrix is high in the thick upper bed of the sequence (Fig. $3 \mathrm{D}$ ), including pebbles to fine cobble clasts. A gravelly lag ( $\mathrm{Gm}$ facies; $0.40-0.70 \mathrm{~m}$ thick) ends the outcropping profile. The interpretation of sedimentary facies indicates gravel bars and bedforms in a gravelly-sandy river.

The highest diversity of phytoliths in this profile was observed in the upper $1.30 \mathrm{~m}$. The phytolith assemblages are quite homogeneous in the first $0.70 \mathrm{~m}$; the non-diagnostic morphotypes occur most frequently in the gravelly lag deposit. The blocky, bulliform flabellate and acute bulbosus morphotypes are the most frequent. The diagnostic grass phytoliths appeared principally with bilobates with convex lobes, short shanks or concave lobes; however, very short shanks and truncated cones were the most frequent. Oblong, crenate and trapezoid morphotypes were also observed but in lower proportions. Herbaceous/woodyshrub dicot, and palm spheroid elements appeared constantly in the samples. The remaining $0.60 \mathrm{~m}$ is characterized by an association of elongate and bulliform flabellate phytoliths. Bilobate, spheroid and rondel phytoliths are scarce. Silicobioliths were mostly worn out, with 


\section{A}
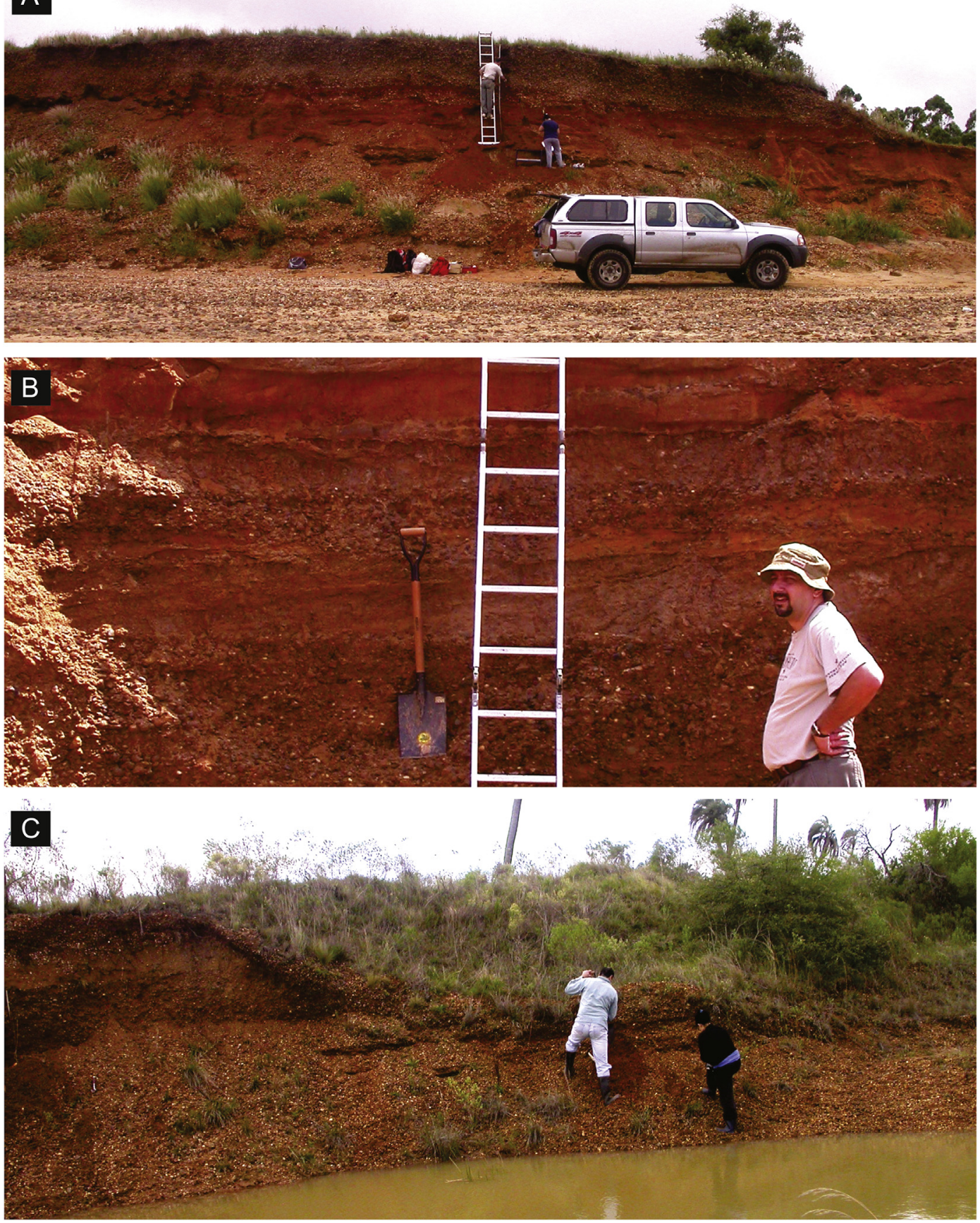

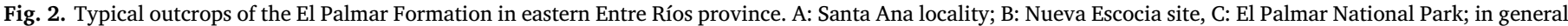
represented by channel deposits (lag gravels, gravelly and sandy bedforms, and dunes).

signs of fluvial transport of high energy.

The Pt index in the samples with phytolith presence shows low values (>10\%); the plant communities might represent a humid psammophile steppe physiognomy (Fig. 7).

José Etchepare profile $\left(32^{\circ} 00^{\prime} 02.6^{\prime \prime} \mathrm{S}, 58^{\circ} 11^{\prime} 27.5^{\prime \prime} \mathrm{W}\right)$. The lower fining upward sequence $(0.40 \mathrm{~m}$ thick) of the profile (with a total of $6.30 \mathrm{~m}$, Fig. 4) is represented by thin beds of matrix-supported cobbles ( $\mathrm{Gm}$ facies), interbedded with poorly sorted yellowish sand beds (Sm facies) and capped by a medium lenticular bed of massive greyish clays with desiccation cracks (Fm facies). The epigenetic reorganization of silica along the profile partially cemented the deposits (Fig. 4 A). The rest of the outcropping profile (5.90 m thick) is, in general, characterized by interbedded medium to thick sandy-gravelly strata. Thin beds formed by very poorly sorted red sands with planar crossbeds or horizontal lamination in some beds or massive (Sp, Sh and Sm facies) are interbedded with thin to medium beds of reddish orange sandy matrixsupported pebbles and cobbles in the lower part, $1.60 \mathrm{~m}$ thick $(\mathrm{Gm}$ facies). Gravelly sediments dominate the upper $4.30 \mathrm{~m}$ of the profile. This part begins with thin to medium horizontal beds formed by clastsupported pebbles and cobbles, with imbrication and horizontal bedding (Gh facies), interbedded with thin lenticular beds of poorly sorted laminated sands (Sh facies). Overlying it are medium to thick beds formed by yellowish sandy matrix-supported cobbles, normally graded ( $\mathrm{Gm}$ facies) to a thick bed of clast-supported cobbles in a scarce sandy matrix reddish, yellow in colour, with horizontal bedding and ironoxide cement; partly imbricated (Gh facies). A very thick bed of reddish 


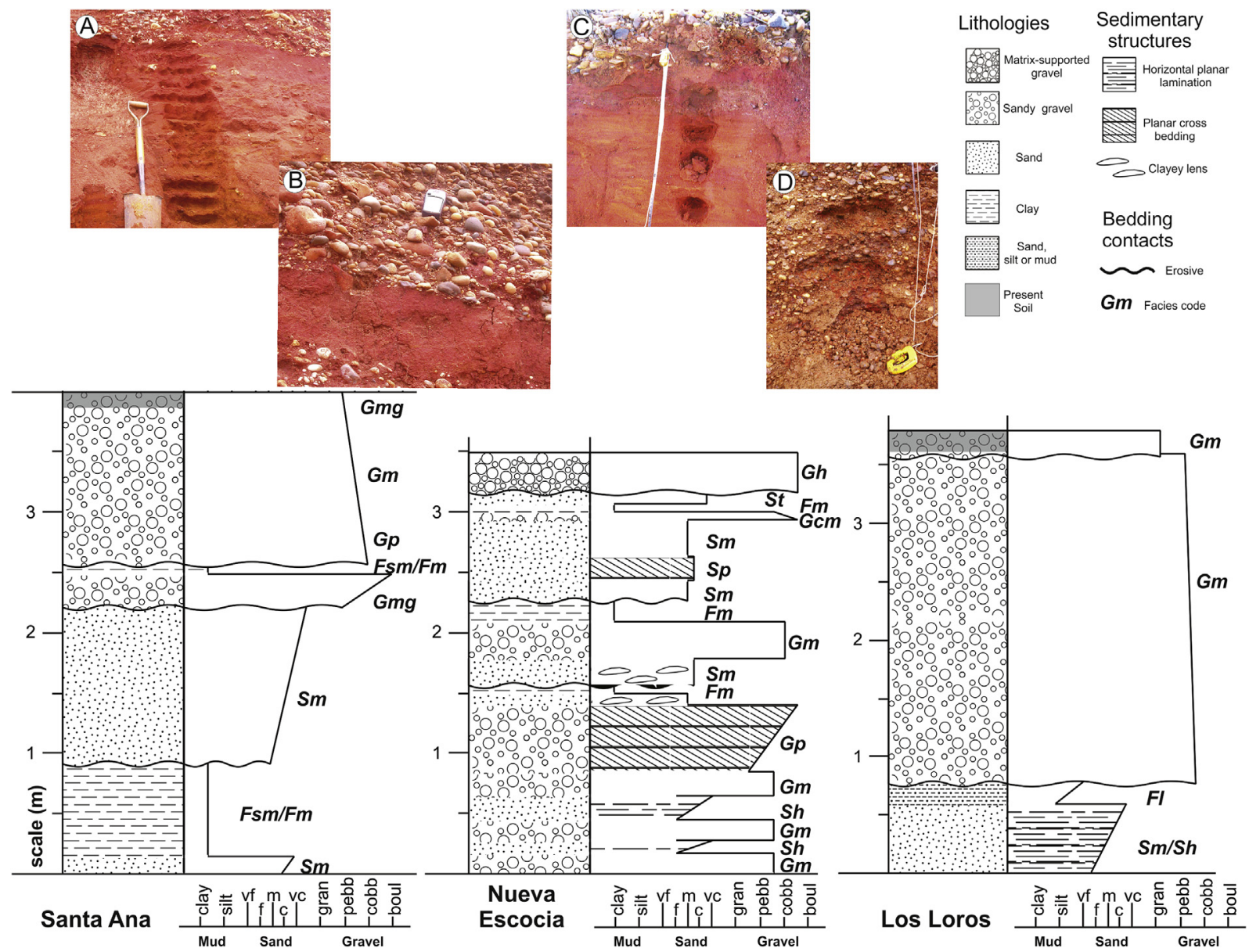

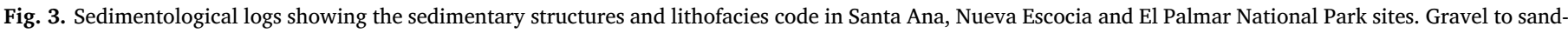

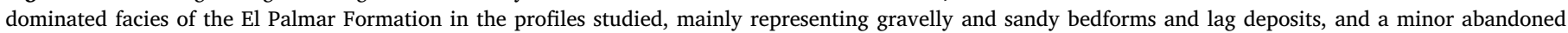
deposit. A and B: A part of the Santa Ana profile; C and D: Sectors of the Los Loros profile.

brown sandy-supported pebbles and cobbles (sub-rounded to wellrounded) is at the top of the sequence. Locally, the gravelly beds are cemented into a duricrust by iron oxides (ferricrete).

Phytolith assemblages in this profile have abundant grass remains characterized by non-diagnostic grass phytoliths (such as the 2029, 2030, 2033 and 2038-2042 samples), with a dominance of elongate elements, bulliform flabellate, blocky, acute bulbosus and tracheids (Fig. 6 F). A large number of bilobates, especially bilobates with concave lobes, short shank; straight lobes, short shank and concave lobes, very short shank, are also abundant. In addition, short saddle, oblong and crenate, rondel and multicellular phytoliths are also present. The spheroid palm morphotypes are frequently observed in assemblages, and ornate globular/wood, and those of dicot shrub affinity, are less frequent.

Two sub-profiles of J. Etchepare, located a few meters from the same exposed profile, were sampled for phytolithic analysis considering the relatively high proportion of fine sediments. Both accessory profiles represent abandoned minor channel deposits (Fig. 4).

José Etchepare profile-Minor sandy channel deposits. The sampled part of the profile ( $1.20 \mathrm{~m}$ thick) partially corresponds to the lower part of the general profile (Fig. 4). It begins with a medium bed composed of poorly sorted very coarse to very fine yellow sands, laminated (Sh facies). This is covered by thin beds formed by poorly sorted yellow sands, including mud clasts, with planar crossbed (Sp facies) marked by iron oxide segregations or laminated. Fine to medium lenticular strata of blocky greyish clays (Fm facies) end the sampled part of the profile (Fig. 4 B). The samples are specially characterized by the presence of multicellular phytoliths (articulated), mainly from epidermal tissues of grasses, found together with short cells and others with bulliform flabellate, as well as elongated, polyhedral and point shaped phytoliths. The diagnostic phytoliths are characterized by large numbers of bilobates, rondels and saddles. Palm spheroid phytoliths are also observed. Other siliceous elements, such as sponge spicules and diatom frustule remains, are also found.

José Etchepare profile- Minor abandoned channel muddy deposits. A thick bed ( $0.77 \mathrm{~m}$ thick) of the profile representing an abandoned channel (Fm facies) was sampled in detail for phytolithic analysis. It is composed of medium beds of grey clays, massive, and with siliceous segregations, interbedded with thin beds of poorly sorted sands and gravels (Fig. 4 C). The clayey infilling of the channel has very frequent non-diagnostic grass phytoliths. Elongate, blocky, bulliform flabellate and acute bulbosus phytoliths are common. The diagnostic phytoliths are present with rondels and collapsed saddles with bambusoid affinity (Fig. 6 D d), and Podostemaceae phytoliths (Fig. 5 E). Palm spheroid phytoliths are observed in a low proportion, as well as globular with a wood/shrub dicot affinity. Other siliceous remains are very frequently observed, such as spicules of sponges with worn surfaces.

The Pt index in the José Etchepare profile shows mean values (10-20\%), the palaeo-communities principally indicate a psammophile steppe physiognomy (Fig. 7).

\subsection{Numerical analysis of the phytolith content}

The principal coordinates analysis (PCoA) accumulates $48 \%$ of the variance in its first two main components (Fig. 8). In the upper 

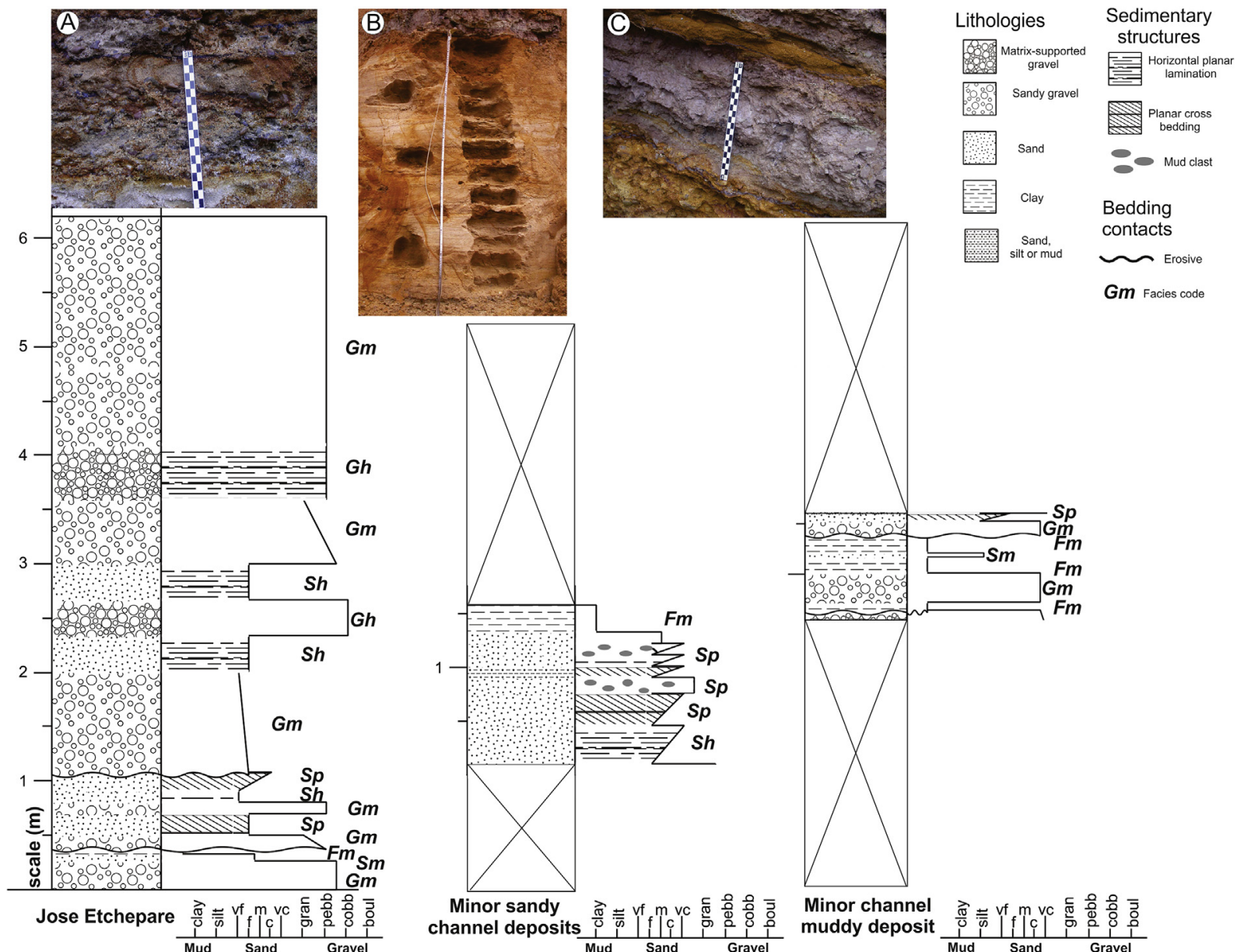

Bedding contacts
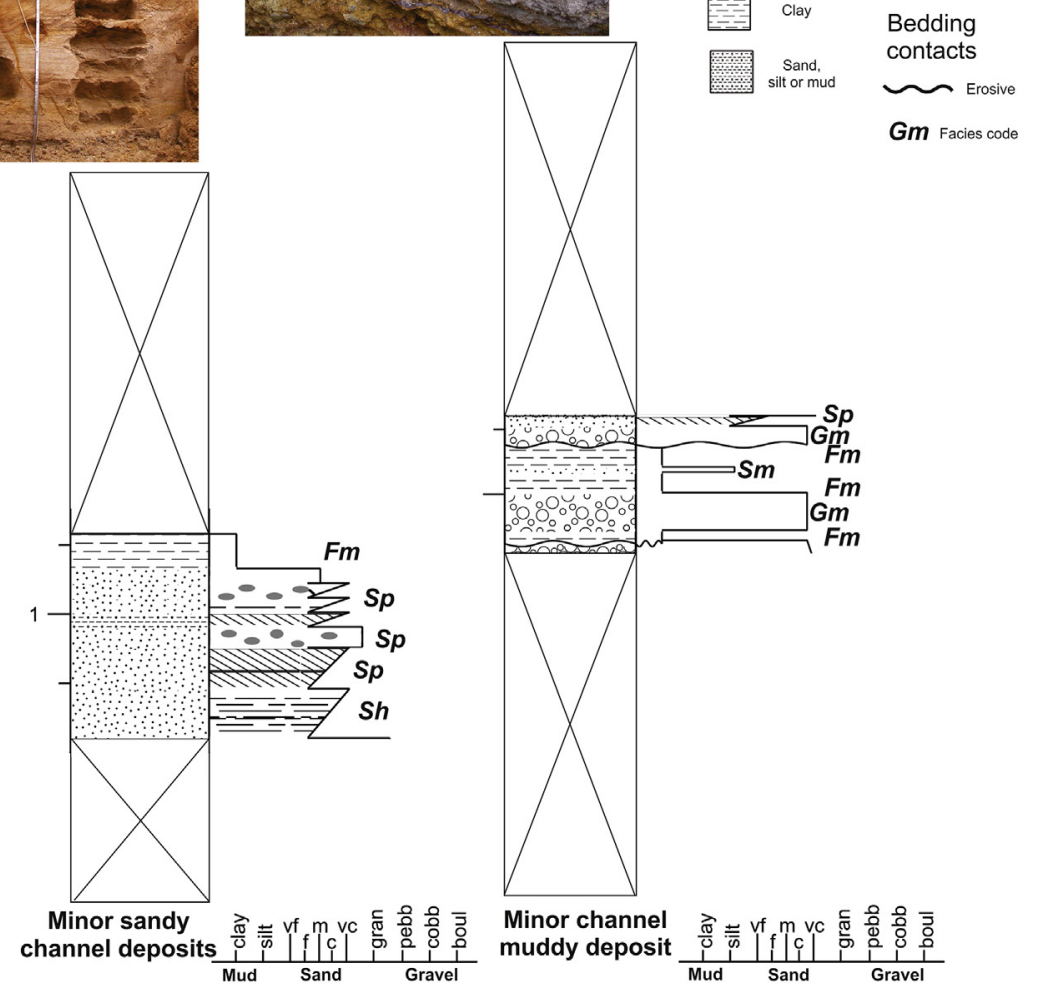

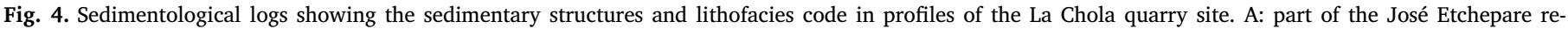
presentative profile; B: minor sandy channel deposits and C: minor muddy abandoned channel.

multivariate space, the samples of Santa Ana, abandoned muddy channel of José Etchepare and lower samples of Los Loros profiles are associated; the phytolith assemblages of these samples show loss of diagnostic phytoliths and an abundant presence of non-diagnostic grass phytoliths. The low proportion of silt in most of the analyzed sedimentary samples might explain the absence of the diagnostic phytoliths. Regarding the inference of palaeoenvironments, in this case we can only conclude the presence of the herbaceous stratum. In the lower multivariate space, the upper samples of Los Loros profile, the José Etchepare representative profile and minor channel deposits are associated. The phytolith assemblages show a high proportion of diagnostic grass phytoliths, palms and arboreal elements. The sedimentary deposits represent a fluvial environment with a major presence of fine to medium sandy matrix and subordinated silt in the gravelly strata. The grasslands, palm/woody savanna and/or forest vegetation characterize this group.

\section{Discussion}

\subsection{Environmental interpretation on the basis of sedimentary characteristics of theEl Palmar Fm}

The interpretation resulting from the studied and sampled stratigraphic profiles is very general due to the absence of outcrop-scale information regarding facies geometry and lateral accretion surfaces. The El Palmar Fm. represents sequences of a large depositional fluvial system reflecting a downstream decrease in the gravel/sand ratio and in the gravel sizes, based on the sedimentary characteristics described in several outcropping profiles along the fluvial valley in its middle river basin by Iriondo and Kröhling (2008). Regarding the recognition of the main fluvial facies (Miall, 1977, 1985, 2014), the depositional environment of the four studied profiles is characterized in this paper, from north to south. Gravel deposits present stable bedforms under an upper flow regime and interbedded lenses of sand bedforms indicate a dune regime. Strata package of sandy gravels or gravelly sands to sands with trough and planar cross-stratification show evidence of a variable flow (Table 1). The Santa Ana profile, at Federación, composed of highenergy facies, represents a major fluvial channel or channel system with longitudinal sandy gravel and gravelly sand bedforms. Fine-grained facies correspond to abandoned channel deposits. The association of the sedimentary facies of the Nueva Escocia profile represents a major fluvial channel with longitudinal sandy gravel bedforms. The sedimentary facies interpretation of the Los Loros profile, located in the type area of the unit (El Palmar National Park), indicates gravel bars and bedforms in a gravelly-sandy river. Comparatively, the José Etchepare profile contains more fine-grained facies (abandoned channel deposits), although sandy-gravelly strata are also present, and intercalated between minor fluvial sandy channels indicating low energy conditions. According to Iriondo and Kröhling (2008), the dominant colour of the formation in most of the outcrops (red to yellowish red) indicates the postdepositional evolution under tropical climatic conditions of the fluvial deposits, mainly represented by the mobilization and segregation of iron oxides. 


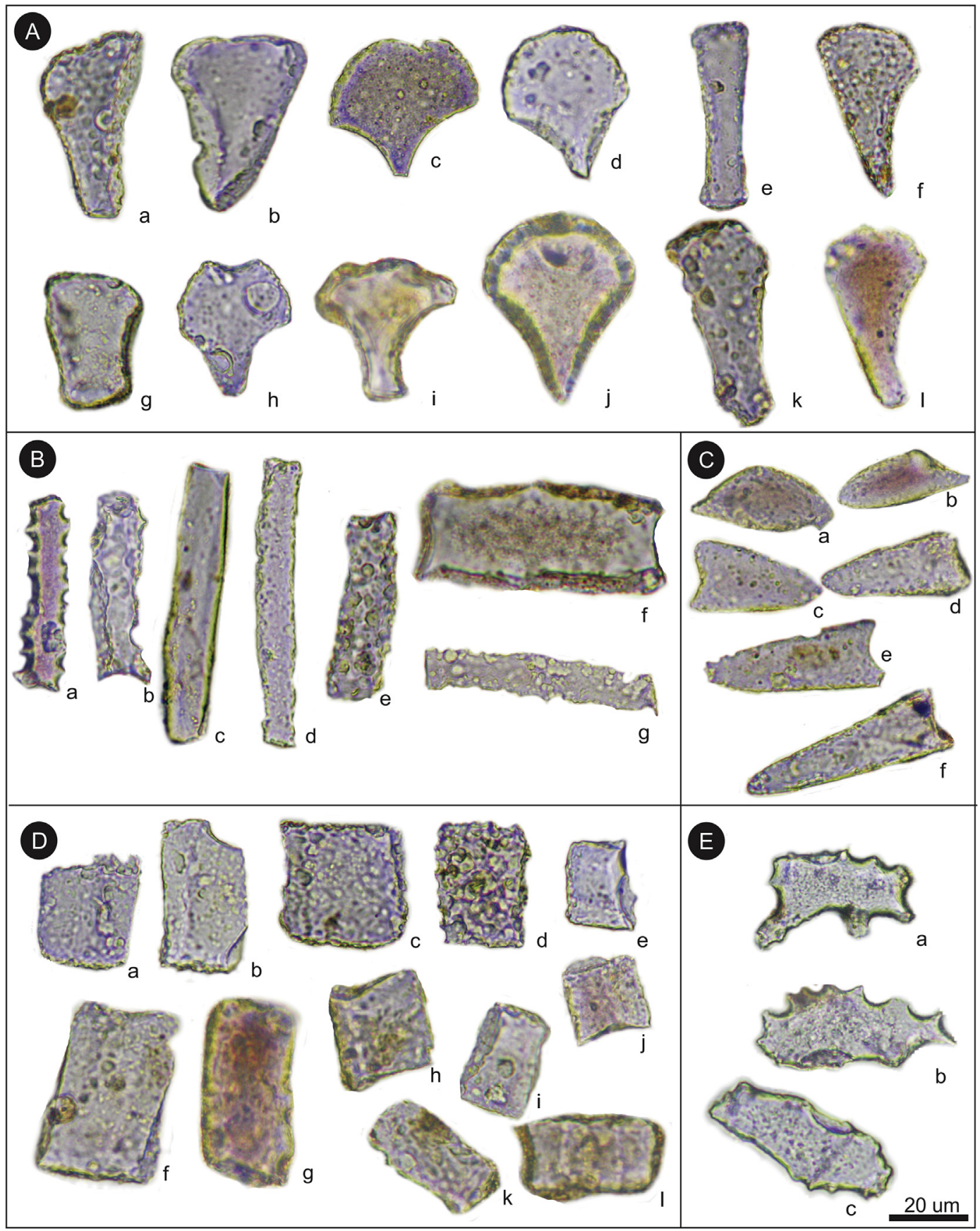

Fig. 5. Non diagnostic phytoliths. A: Bulliform flabellate (Fan Shaped), B: Elongate grass phytoliths, C: Acute bulbosus, D: Blocky (Polyhedral), E: Podostemaceae phytoliths.

\subsection{El Palmar Fm. fossil assemblages}

The phytolith assemblages of the El Palmar Fm. in four new fossiliferous localities are described. In the Santa Ana fossiliferous locality, two clearly separated phytolith assemblages are observed. In the lower levels, an association with non-diagnostic grass morphotypes and an evident loss of the diagnostic phytoliths is detected; the assemblage is associated with low flow regime. In the top section, an increase in the diversity of palm and tree morphotypes is described, associated with Danthonioideae and Panicoideae grasses with a lower abundance of Pooideae and Chloridoideae grass subfamilies. In this locality, the phytolith assemblages characterize paleocommunities that could be represented by shrubbery with an isolated tall palm physiognomy according to the Pt index. Patterer et al. (2019) described this physiognomic unit as plant communities characterized by the presence of shrub-grassland with scattered palm trees and occasional low shrubs; the herbaceous stratum covers more than $70 \%$ of the surface in a continuous form. The high flow regime (represented by gravelly channel lithofacies in the upper part of the sampled profile) is also marked by the phytolith assemblages, which present a high frequency of morphotypes with signs of wear from physical processes and transport (Fig. 9).

At the Santa Ana locality, the fossil woods recorded are Mimosoxylon caccavariae Brea et al. (2010), Prosopisinoxyon castroae Brea et al. (2010), Amburanoxylon tortorellii Brea et al. (2010) and Holocalyxylon cozzoii Brea et al. (2010), all belonging to the Fabaceae family, and Herbstii schinopxylon Lutz (1979), an Anacardiaceae. These morphospecies found in the El Palmar Fm. are of allochthonous origin. They also 


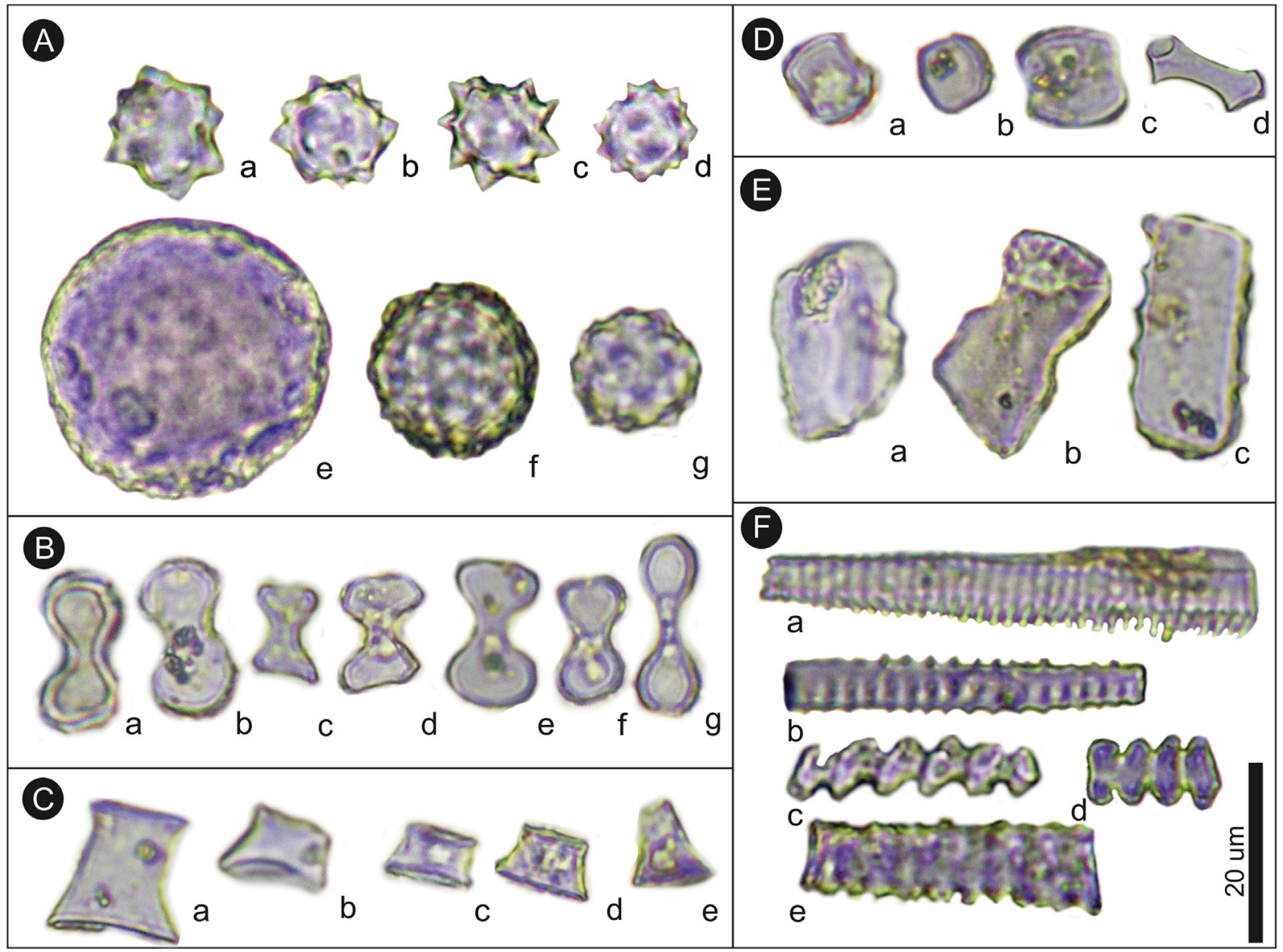

Fig. 6. Diagnostic phytoliths. A. Spheroid phytoliths: a, b, c and d, palm spheroids; e, f and g, spheroid woody dicots. B. Bilobates. C. Rondels. D. Saddles. E. Trapezoids. F: Tracheids.

form part of a heterogeneous environment: 1) a gallery forest in a humid tropical to subtropical climate, and 2) a semi-arid forest, which suggests a warm-temperate semiarid-humid environment (Brea et al., 2010). Ramos et al. (2015) described the first record of Cryptocaryoxylon Leisman in the Paraje Salto Grande locality, Federación. The anatomical characteristics suggest a relationship with Cryptocarya (Laureaceae), being consistent with a warm-temperate and humid climate during part of the Upper Pleistocene.

The presence of phytolith assemblages has been recorded in the Los Loros profile, in El Palmar National Park. Non-diagnostic phytoliths with surfaces worn by active fluvial transport are common. The diagnostic phytoliths are frequently observed and within this group the presence of grass and palm morphotypes is constant, Panicoideae and Danthonoideae subfamilies are common, whereas Chloridoideae and Pooideae are scarce. These elements do not present any signs of damage from fluvial transport. The phytolith assemblage might indicate the presence of palaeocommunities with a physiognomy of humid psammophile steppe according to the Pt index. This agrees with conclusions of Patterer et al. (2019) who state that the El Palmar unit shows a physiognomy of steppe with grasses and shrubs, with a scattered cover of small trees and some palms. Zucol et al. (2005) describe a profile in El Palmar National Park with two clearly distinguishable phytolith assemblages. This interpretation suggests a source with heterogeneous material and a marked influence of fluvial deposits and continental elements, such as palm and grass phytoliths. As for its preservation, some of the morphotypes present worn surfaces, showing a large amount of transport before deposition, typical of fluvial deposits (Zucol et al., 2005; Patterer, 2012; Patterer et al., 2014). Ramos et al. (2012), described three Fabaceae species of fossil wood in the El Palmar Fm.
(Nueva Escocia, Concordia, and Colón profiles): Beilschmiedioxylon parataubertiana, Terminalioxylon lajaum and Piptadenioxylon chimeloi. The fossil wood would correspond to components of mixed riparian forests (Lauraceae and Combretaceae) and mixed semi-arid forests (Fabaceae). Ramos (2015) analyzed a total of sixteen autochthonous and forty parautochthonous fossil woods in eight fossiliferous localities. The paleocommunities of the El Palmar Fm. correspond to the arboreal type of evergreen tropical forest with an ecotonal zone with subtropical forest with two to three arboreal strata integrated by the Fabaceae, Anacardiaceae, Combretaceae, Apocynaceae, Vochysiaceae, Malvaceae and Podocapaceae families. Recently, Ramos et al. (2017a,b) described Bastardiopsis palaeodensiflora that indicates that this fossil grew under warm-temperate and humid conditions, and they also described Paraoxystigma concordiensis and Gossweilerodendroxylon palmariensis of the first Detarioideae fossil wood in the El Palmar Fm. This fossil suggests warm and humid climatic conditions for the upper-middle basin of the Uruguay river during some periods in the Upper Pleistocene.

The palaeobotanical record of the El Palmar Fm. differs from the paleocomunnities described (Patterer et al., 2017) in sandy soils developed on Late Holocene dissipated aeolian dunes covering the Holocene lower fluvial terrace of the Uruguay river valley (Iriondo and Kröhling, 2008) in eastern Entre Ríos province. There, the phytolith assemblages show change in the physiognomy of the vegetation and the retraction of the Butia yatay Mart. Becc. palms. Two phytolith assemblages were observed; one is the palm forest associated with a poor herbaceous stratum, and the other is a meso-megathermal grassland in the upper section of the profile associated with the present soil (Patterer et al., 2017).

In La Chola quarry (J. Etchepare profile), the upper gravelly stratum 

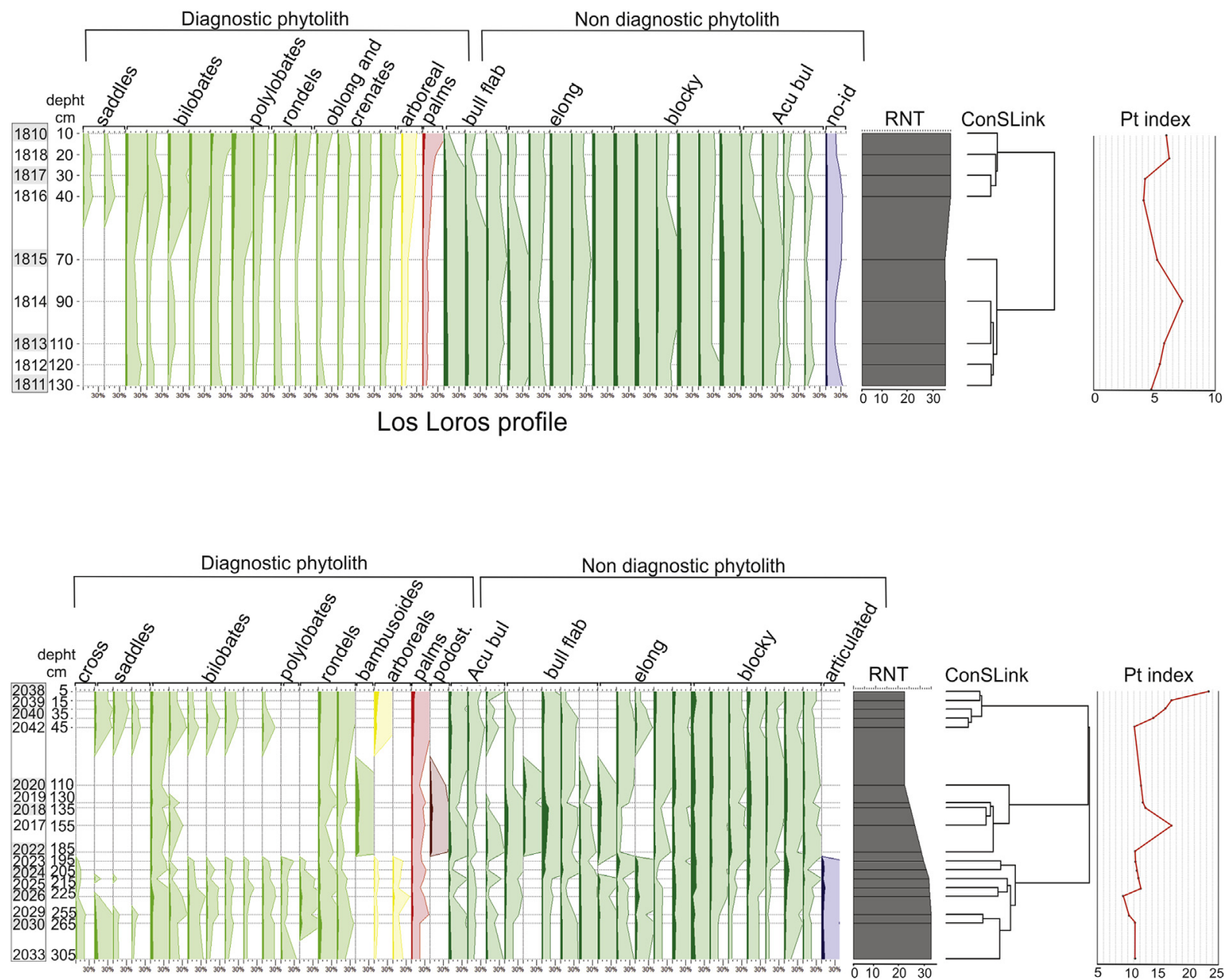

José Etchepare profile

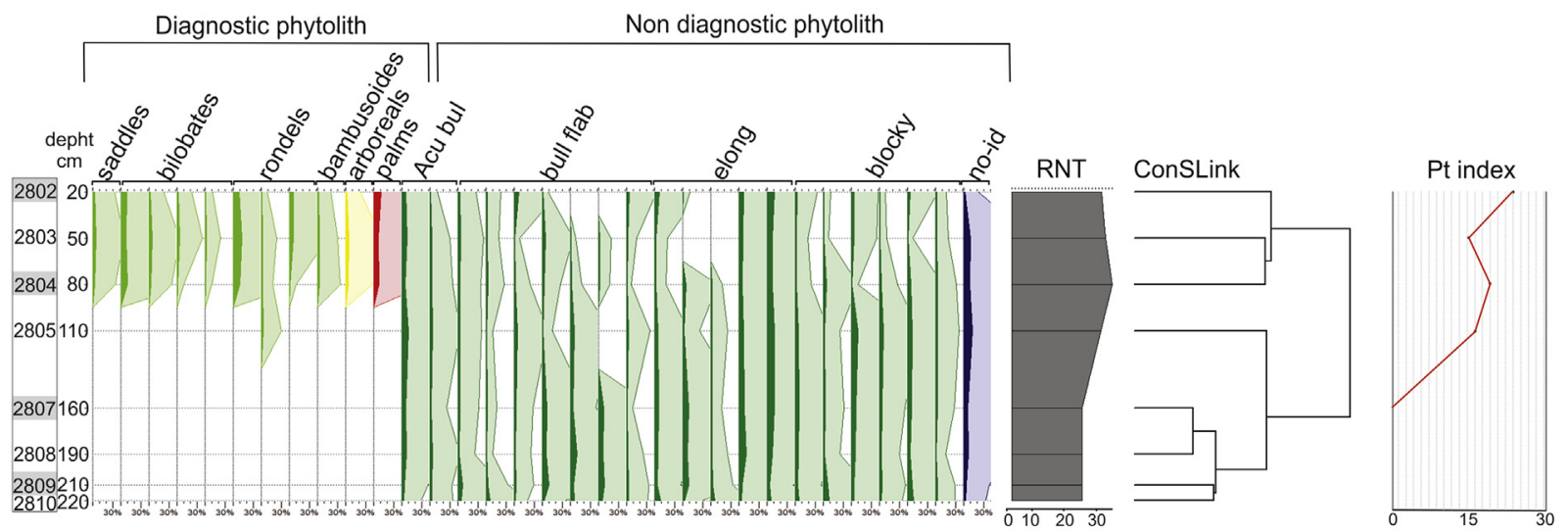

Santa Ana profile

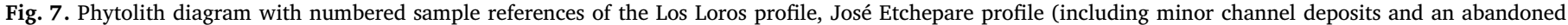
channel) and the Santa Ana profile. Rarefacted number of taxa (RNT) and ConsLink.

of the El Palmar Fm. shows phytoliths of Panicoideae and Danthonioideae grasses, together with dicotyledons and palms. The Pt index characterizes palaeocommunities of the psammophile steppe physiognomy, this unit presents grassland or grass steppe features with some very isolated tall palms that are associated with sandy deposits at the headwaters of the streams (Patterer et al., 2019). In the minor abandoned muddy channel deposits, the phytolith assemblages were characterized by the Bambusoideae and Podostemaceae families, this vegetation suggests very humid environments with waterbodies and a warm climate. In the lower bed of the minor sandy channel deposits the 


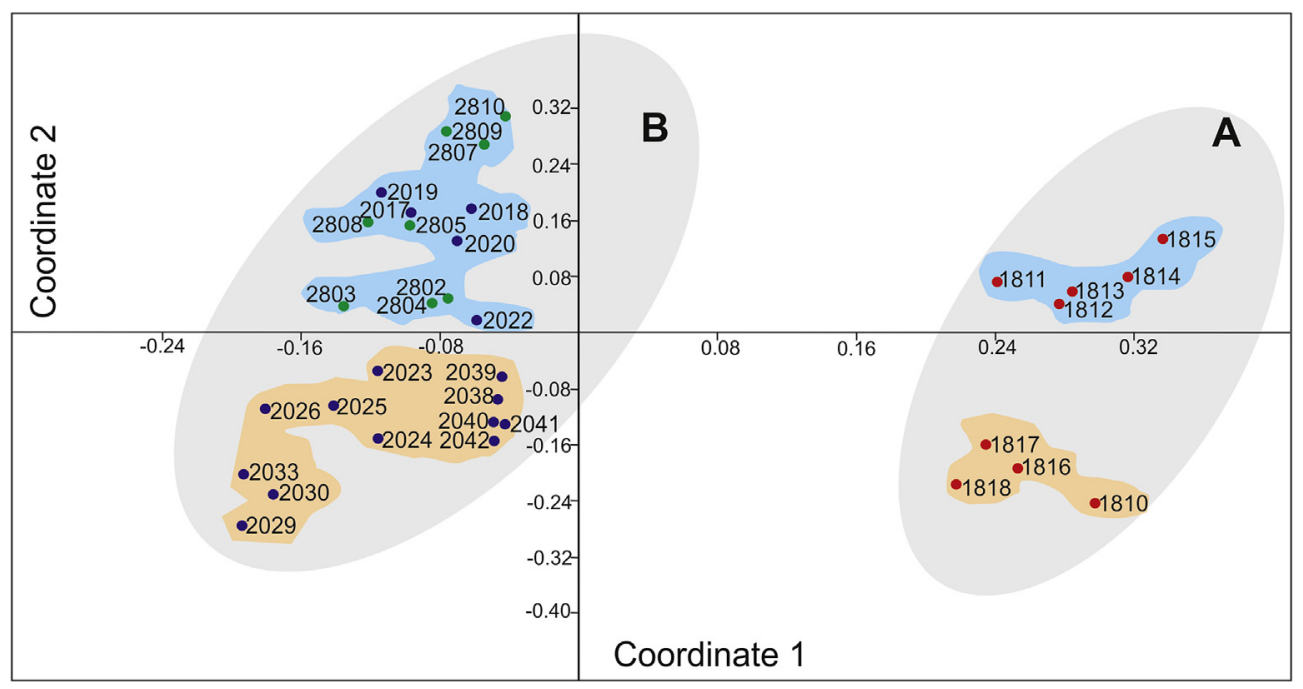

Fig. 8. Principal Coordinates Analysis (PCoA) of different samples. Los Loros samples (red), José Etchepare samples (blue) and Santa Ana samples (green). (For interpretation of the references to colour in this figure legend, the reader is referred to the Web version of this article.)

variability of phytoliths is greater; Panicoideae, Danthonioideae, Chloridoideae grasses are very abundant, as well as non-diagnostic grasses. Palm and tree morphotypes are present in the phytolith assemblages. The phytolith records suggest varied environments, such as megathermic palm savannas and open forests.

The results obtained agree with the data presented by Zucol et al. (2005); Brea et al. (2010) and Ramos et al. (2012), who suggest heterogeneous micro-environments: mixed, palm, humid gallery and semiarid forests, all developed under temperate-warm, humid to semiarid climatic conditions during some events of the Upper Pleistocene related to the deposition of the El Palmar Fm. in the middle Uruguay river basin (on the right margin of the present river channel). The Salto Fm. in its type area (on the left margin of the present river channel; Salto area, Uruguay), a unit that is correlated with the El Palmar Fm., has phytolith assemblages that show an association of grassland and palm trees paleocommunities in a temperate/warm climate (Patterer et al., 2018).

At present, the community of Butia yatay palm trees is limited to El Palmar National Park and "La Aurora del Palmar" private reserve, located in the Colon department, eastern Entre Rios province. The vegetation is distributed in mosaics, including forests on the banks of rivers and streams, tall grass on floodplain wetlands, xeric steppes on sandy outcrops and savannas of palm trees dominated by B. yatay on the interfluves (Movia and Menvielle, 1994). Outside the park, the vegetation is mainly attributed to a physiognomy of pasture type, with a large presence of grasses of the following genera: Axonopus, Paspalum, Digitaria, Schizachyrium and Bothriochloa and limited Piptochaetium, which are associated with shrubs and herbs (León et al., 1991).

Once a plant dies, the phytoliths are released into the environment due to decomposition of the organic matter. According to Madella and Lancelotti (2012), in general phytoliths are not transported over long distances because they are relatively "heavy" particles, but there are situations in which transport may be an important factor in the making of an assemblage; e.g. dry environments with sparse vegetation and strong winds or environments with heavy precipitations and important runoff. In the sediment, the silica bodies are exposed to transport that could mechanically damage their bodies. The result of transport (by wind and/or water) may be breakage, chipping of the main body and/ or abrasion (Madella and Lancelotti, 2012).

In this study, we have been able to identify phytoliths that exhibit different degrees of weathering, mainly in the gravelly and clayey deposits (Fig. 9). For example, bulliform flabellate (Fig. 9 a, b, c and d), elongate (Fig. 9 j, k and l) and spheroid phytoliths (Fig. $9 \mathrm{~h}$ and i) are observed with a presence of hollows, generated during fluvial transport processes, indicating an extensive level of deterioration by a mechanical agent in a high-energy environment. A consequence of the transport is a complete modification of the silica body characteristics (especially in the case of strong abrasion), as in the case of the phytoliths (Fig. 9: e, f and g), which are impossible to identify correctly. Particularly, in the clayey deposits, the presence of the phytoliths with signs of surface corrosion might correspond with high alkalinity of the environment and this condition can result in a high degree of dissolution, with fragmented and/or dissolved phytoliths, and an important amount of silica debris (Ramírez S. et al., 2007). There are situations in which transport and/or a high alkaline environment could be an important factor in the formation of phytolith assemblages. Zucol et al. (2005) describe the same surface wear condition in some morphotypes of the assemblage phytoliths in the El Palmar Fm.

Due to the characteristics of the sediments found in the El Palmar Fm., it is important to take into account which phytolith morphologies might be from local plants (for instance non-degraded or multicellular phytoliths), and which other morphotypes were transported from other areas upstream (for instance, degraded phytoliths). In order to interpret the communities that have developed in the region it is necessary a new study to explain the presence and/or absence of specified phytolith morphotypes in different sedimentary samples of the El Palmar Fm.

\section{Conclusion}

In this paper, new information about micro-paleobotanical records has been added for the new fossiliferous localities in the middle basin of the Uruguay river valley (eastern Entre Ríos province, Argentina), increasing the palaeobiodiversity knowledge of some events in the Upper Pleistocene. In particular, the El Palmar Formation represents a channel system of the Uruguay river, with longitudinal sandy gravel and gravelly sand bedforms and with associated overbank and abandoned channel deposits.

Our results principally describe the herbaceous palaeoflora of the unit, which were represented by mixed environments. On the one hand; meso-megathermic grasses with presence of palm trees in a savanna ecosystem and, on the other hand; micro-environments with aquatic plants and bamboo grasses that characterized stratified forest of humid environments with great water availability. These results have helped to better understand and interpret the evolutionary history of these communities, i.e., the palm trees now located in El Palmar National Park reserve would be part of a relict flora that has inhabited the area since, at least, the Upper Pleistocene. The reconstructed vegetation 


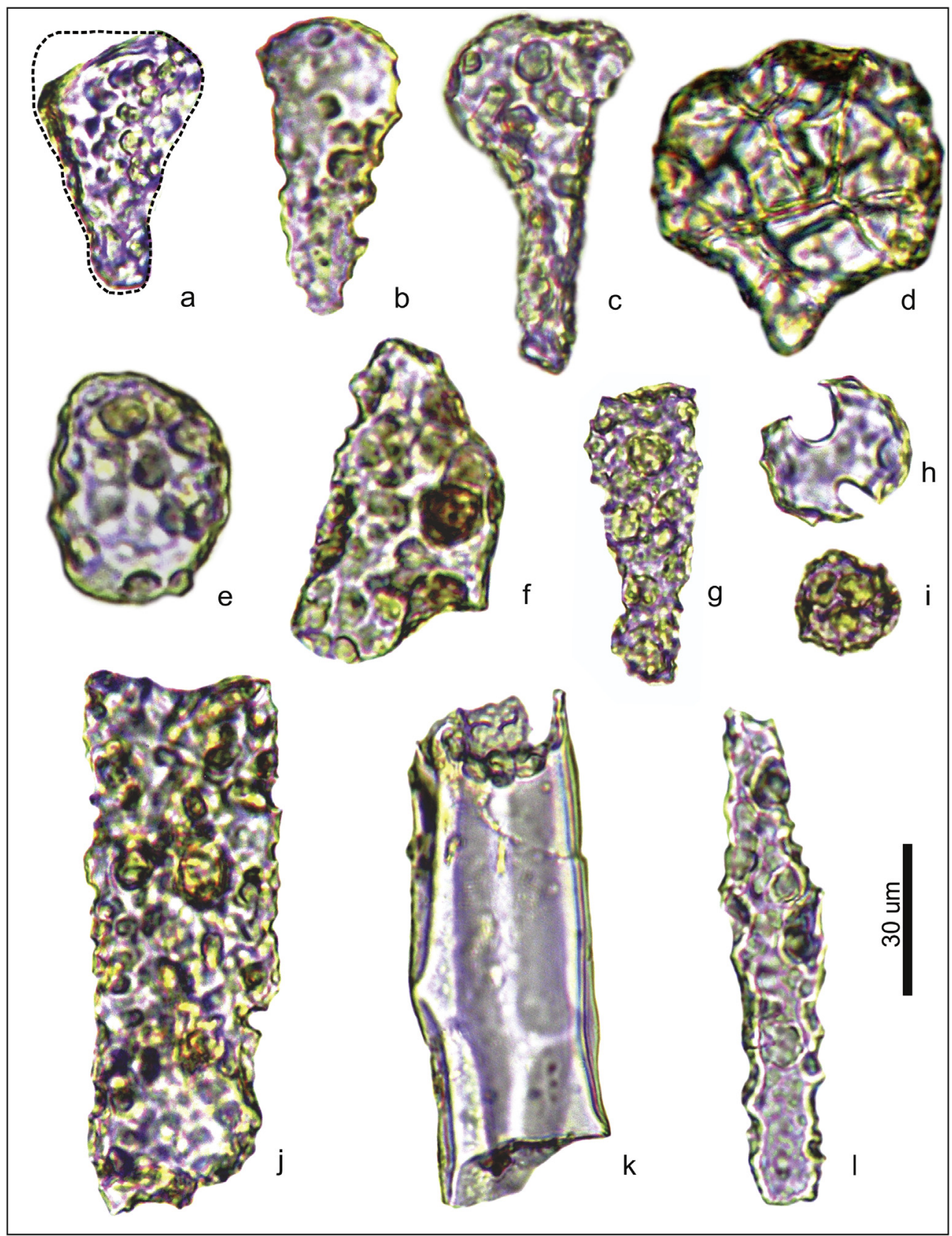

Fig. 9. Phytoliths with different degrees of weathering: a, b, c and d, different alteration degrees in bulliform flabellate phytoliths; e, $\mathrm{f}$ and $\mathrm{g}$, not identified phytoliths; $\mathrm{h}$ and $\mathrm{i}$, globular phytoliths with damaged surfaces; $\mathrm{j}$, and $\mathrm{l}$, elongated with hollows on surface; $\mathrm{k}$, phytoliths with chipping body.

pattern is composed of a stratified gallery forest changing to temperate savanna, extended along the upper basin of the Uruguay river and occupying the river valley in the middle reach of the basin. The sedimentological and palaeobotanical indicators of the El Palmar Fm. show general warm and humid conditions, at least during the deposition of the upper part of the formation, with ages obtained that would represent the warm substage MIS 5a, probably covering most of the last major interglacial period before the present (MIS 5).

\section{Authorship statement}

Conception and design of study: N.I. Patterer, D.M. Kröhling, A.F. Zucol, acquisition of data: N.I. Patterer, D.M. Kröhling, A.F. Zucol, analysis and/or interpretation of data: N.I. Patterer, D.M. Kröhling, A.F. Zucol, Drafting the manuscript: N.I. Patterer, D.M. Kröhling, A.F. Zucol, revising the manuscript critically for important intellectual content: N.I.
Patterer, D.M. Kröhling, A.F. Zucol, Approval of the version of the manuscript to be published.

\section{Acknowledgements}

The authors thank the administration of El Palmar National Park, La Chola II and Nueva Salvia quarries. We extend our thanks to Aristobulo Maranta (the former Intendant of EPNP). To Rosemary Scoffield, a native English speaker, for her assistance in language revision. This paper was financially supported by the Agencia Nacional de Promoción Científica y Tecnológica (ANPCyT; Argentina), Project PICT 2008 $\mathrm{N}^{\circ} 0176$ and PICT $2015 \mathrm{~N}^{\circ} 0221$.

\section{References}

Bossi, J., 1969. Geología del Uruguay. Universidad de la República, Departamento de 
Publicaciones, pp. $4642^{\circ}$ Edición. Colección Ciencias 12.

Brandoni, D., Ferrero, B.S., Brunetto, E., 2010. Mylodon darwini owen (xenarthra, Mylodontinae) from the late Pleistocene of mesopotamia, Argentina. Remarks on individual variability, paleobiology, paleobiogeography, and paleoenvironment. J. Vertebr. Paleontol. 30, 1547-1558.

Brea, M., 1998. Ulminium mucilaginosum n.sp. y Ulminium artabeae n. sp., Dos leños fósiles de Lauraceae en la Formación El Palmar, provincia de Entre Ríos, Argentina. Ameghiniana 35, 193-204.

Brea, M., 1999. Leños fósiles de Anacardiaceae y Mimosaceae de la Formación El Palmar (Pleistoceno superior), departamento de Concordia, provincia de Entre Ríos, Argentina. Ameghiniana 36, 63-69.

Brea, M., Zucol, A.F., 2011. The Paraná-Paraguay basin: geological and paleoenviromental (Chapter 4) In: Albert, J.S., Reis, R.E. (Eds.), Historical Biogeography of Neotropical Freshwater Fishes. University of California Press, pp. 69-87 388.

Brea, M., Zucol, A.F., Patterer, N.I., 2010. Fossil woods from late Pleistocene sediments from el Palmar Formation, Uruguay basin, eastern Argentina. Rev. Palaeobot. Palynol. 163, 35-51.

Calegari, M.R., Lopes Paisani, S.D., Cecchet, F.A., de Lima Ewald, P., Osterrieth, M.L., Paisani, J.C., Pontelli, M.E., 2017. Phytolith signature on the araucarias plateau vegetation change evidence in late quaternary (South Brasil). Quat. Int. 434 117-128.

Dinerstein, E., Olson, D.M., Graham, D.J., Webster, A.L., Primm, S.A., Bookbinder, M.P., Ledec, G., 1995. Una Evaluación del Estado de Conservación de las Ecorregiones de América Latina y el Caribe. Publ. Banco Mundial- Fondo Mundial para la Naturaleza, pp. 135 y mapas. Washington.

Ferrero, B., Brandoni, D., Noriega, J.I., Carlini, A.A., 2007. Mamíferos de la Formación El Palmar (Pleistoceno tardío) de la provincia de Entre Ríos, Argentina. Rev. Mus. Argent. Cienc. Nat. 9 (2), 109-117.

Iriondo, M., Kröhling, D., 2008. Cambios ambientales en la cuenca del Uruguay (desde el Presente hasta dos millones de años atrás). Colección Ciencia y Técnica, Universidad Nacional del Litoral, Santa Fe, pp. 330.

Kröhling, D., 2009. La Formación El Palmar, una unidad fluvial asignable al subestadio cálido EIO 5a (Pleistoceno Tardío) de la cuenca del río Uruguay. Nat. Neotrop. 40, 61-86.

Kröhling, D., Brunetto, E., Galina, G., Zalazar, M.C., Iriondo, M., 2014. Planation surfaces on the parana Basaltic Plateau, South America. In: Rabassa, J., Ollier, C., Doe, R. (Eds.), Gondwana Landscapes of Southern South America. (Earth System Sciences). General Editor. Springer Science and Business Media, Dordrecht, pp. 247-303.

León, R.I.C., Sala, O.E., Lavado, R.S., Deregibus, V.A., Cahuépé, M.A., Scaglia, O.A., Velázquez, C.A., Lemcoff, H., 1991. Río de la Plata grasslands. In: Coupland, R. (Ed.), Ecosystems of the World 8A, Natural Grassland, Introduction and Western Hemisphere. Elsevier, pp. 367-407.

Lutz, A.I., 1979. Maderas de angiospermas (Anacardiaceae y Leguminosae) del Plioceno de la provincia de Entre Ríos, Argentina. Facena 3, 39-63.

Lutz, A.I., 1980. Palmoxylon concordiense n. sp. del Plioceno de la Provincia de Entre Ríos, República Argentina. In: II Congreso Argentino de Paleobotánica y Bioestratigrafía y I Congreso Latinoamericano de Paleontología. Tomo III, pp. 129-140 Buenos Aires.

Lutz, A.I., 1984. Palmoxylon yuqueriense n. sp. del Plioceno de la Provincia de Entre Ríos, Argentina. III Congreso Argentino de Paleontología y Bioestratigrafía. Actas, pp. 197-207 (Corrientes).

Lutz, A.I., 1986. Descripción morfo-anatómica del estípite de Palmoxylon concordiense Lutz del Plioceno de la provincia de Entre Ríos, Argentina. Facena 6, 17-32.

Madella, M., Lancelotti, C., 2012. Taphonomy and phytoliths: a user manual. Quat. Int. 275, 76-83.

Miall, A.D., 1977. A review of the braided- river depositional environment. J. Sedimetary Petrol. Earth Sci. Rev. 13, 1-62.

Miall, A.D., 1985. Architectural-element analysis: a new method of facies analysis applied to fluvial deposits. Earth Sci. Rev. 22, 262-308.

Miall, A.D., 1996. The Geology of Fluvial Deposits: Sedimentary Facies, Basin Analysis and Petroleum Geology. Springer-Verlag, Inc., Heidelberg, pp. 582.

Miall, A.D., 2014. Fluvial Depositacional Systems, Springer Geology. Springer International Publishing Switzerland, pp. 215.

Movia, C., Menvielle, M.F., 1994. Mapa de vegetación. In: Plan de Manejo del Parque, Nacional El Palmar. Administración de Parques Nacionales, Argentina.

Neumann, K., Strömberg, C.A.E., Ball, T., Albert, R.M., Vrydagh, L., Scott Cumming, L.,
2019. International code for phytolith nomenclature (ICPN) 2.0. Ann. Bot. XX, 1-11. https://doi.org/10.1093/aob/mcz064. 2019.

Patterer, N.I., 2012. Análisis Fitolíticos de la Formación El Palmar (Pleistoceno superior) en la cuenca del río Uruguay (este de Argentina). Ph.D. thesis. Universidad Nacional de Córdoba, pp. 307.

Patterer, N.I., Brea, M., 2011. Phytolith analysis in fluvial sediments of el Palmar Formation (late Pleistocene) in eastern Argentina. In: 8th International Meeting on Phytolith Research. Estes Park, Colorado, USA. Sept. 15-17. Abstracts, pp. 42-43.

Patterer, N.I., Passeggi, E., Zucol, A.F., 2011. Análisis fitolíticos de suelos del sudoeste de la Provincia de Entre Ríos (Argentina) como una herramienta para comprender sus procesos pedológicos. Rev. Mex. Ciencias Geol. 28 (1), 132-146.

Patterer, N.I., Zucol, A.F., Brea, M., 2014. Análisis fitolíticos del perfil sedimentario Los Loros, de la Formación El Palmar (Pleistoceno superior), en el Parque Nacional El Palmar, Entre Ríos, Argentina. Acta Geol. Lilloana 26 (1), 53-62.

Patterer, N.I., Passeggi, E., Zucol, A.F., Zappala, F., 2016. Técnicas de muestreo y procesamiento para la obtención de microrestos en muestras sedimentarias fluviales. Caso de estudio: Formación El Palmar. In: Zucol, A.F., Patterer, N.I., Colobig, M.M., Moya, E. (Eds.), Taller Micropaleoetnobotánica Relevancia de una Red Interdisciplinaria de Investigaciones en Fitolitos y Almidones. Libro de Resúmenes. 222pp, pp. 31-37 ISSN 2525-0876.

Patterer, N.I., Zucol, A.F., Passeggi, E., 2017. Análisis fitolíticos en suelos formados sobre antiguas terrazas del Río Uruguay (Colón, Entre Ríos): primera evidencia de retracción de los palmares de Butia yatay (Mart.) Becc. Publicación Electrónica de la Asociación Paleontológica Argentina 17 (1), 1-13.

Patterer, N.I., Kröhling, D., Passeggi, E., 2018. Análisis Fitolíticos de un perfil de la Formación Salto (Pleistoceno) en su área tipo, noroeste de Uruguay. Bol. de la ALPP, $\mathrm{N}^{\circ}$ 18, 103-104 ISSN 0325-0121.

Patterer, N.I., Zucol, A.F., Fernández Pepi, M.G., Brea, M., 2019. Plant and soil phytolith analysis of a relictual community of Butia yatay in temperate-humid savannas (Entre Ríos, Argentina). Quat. Int. 525, 126-139.

Ramírez S, H.U., Zárate del V, P.F., García G, M.E., de la Torre V, O., Israde A, I., Meulenert P, A.R., 2007. Disolución de sílice biogénica en sedimentos de lagos utilizados como bioindicadores de calidad del agua. e-Gnosis 5 (4), 1-19.

Ramos, R.S., 2015. Estudios xilológicos en el Pleistoceno superior de la Formación El Palmar, provincia de Entre Ríos, Argentina. PhD Thesis. Universidad Nacional de Córdoba, Argentina, pp. 356.

Ramos, R.S., Brea, M., Kröhling, D.M., 2012. Leños fósiles de la Formación El Palmar (Pleistoceno Tardío) en el Parque Nacional El Palmar, Entre Ríos, Argentina. Ameghiniana 49 (4), 606-622.

Ramos, R.S., Brea, M., Kröhling, D.M., 2015. Primer registro de Cryptocaryoxylon Leisman, una Lauraceae de la Formación el palmar (Pleistoceno tardío), Entre Ríos, Argentina. Rev. del Museo Argentino de Ciencias Naturales Bernardino Rivadavia 17 (1), 59-70.

Ramos, R.S., Brea, M., Kröhling, D.M., 2017a. Malvaceous wood from the late Pleistocene el Palmar Formation of northeastern Argentina. Rev. Palaeobot. Palynol. 246, $232-241$.

Ramos, R.S., Brea, M., Kröhling, D.M., 2017b. Fossil woods of Detarioideae subfamily (Fabaceae) from el Palmar formation (late Pleistocene) in south America. J. South Am. Earth Sci. 79, 202-214.

Tonni, E.P., 1987. Stegomastodon platensis (Mammalia, Probocidae, Gomphotheriidae) y la antigüedad de la Formación El Palmar en el Departamento Colón, Provincia de Entre ríos, República Argentina. Ameghiniana 2 (3-4), 323-324.

Ubilla, M., Martínez, S., 2016. Geology and Paleontology of the Quaternary of Uruguay. Springer Briefs in Earth System Sciences. Springer, pp. 77.

Veroslavsky, G., Ubilla, M., 2007. A snapshot of the evolution of the Uruguay river (del Delta basin): the Salto depositional sequence (Pleistocene, Uruguay, South America). Quat. Sci. Rev. 26, 2913-2923.

Zucol, A.F., Brea, M., Scopel, A., 2005. First record of fossil wood and phytoliths assemblages of the upper Pleistocene in el palmar national park (Argentina). J. Am. Earth Sci. 20 (1-2), 33-43.

Zucol, A.F., Passeggi, E., Brea, M., Patterer, N.I., Fernández Pepi, Ma G., Colobig, M.M., 2010. Phytolith analysis for the Potrok Aike Lake drilling proyect: sample treatment protocols for the pasado microfossil manual". In: Corbella, H., Maidana, N.I. (Eds.), $1^{\text {a }}$ Reunión Interno dos del Proyecto Interdisciplinario Patagonia Austral y 1er Workshop Argentino del Proyecto Potrok Aike Maar Lake Sediment Archive Drilling Project. Proyecto Editorial PIPA, Buenos Aires, Argentina, pp. 81-84. 